\title{
From cherry-picking to control: migrant labour and its exploitation in finnish governmental policies
}

\author{
Av Natalia Ollus ${ }^{1}$ og Anne Alvesalo-Kuusi ${ }^{2}$
}

\begin{abstract}
This paper examines the way in which the exploitation of migrant labour was portrayed in Finnish governmental policy documents during the years 19952012. The analysis shows that the promotion of migrant labour and the prevention of economic crime were both central themes of government policy during the period under scrutiny. Migrant labour, especially when skilled, was portrayed in government policies as a solution to the aging population and the demand for labour. Increased migration was also seen to involve certain risks and unwanted elements, though it was believed that these could be managed through control measures targeting unwanted immigration. The regulation of economic crime and the misuse of migrant labour were mainly addressed in the framework of problems related to tax revenue, fair competition and market function. The analysis shows that migrant labour is the subject of several levels of control, but that this control primarily serves to protect and secure the conditions of the Finnish labour market and ultimately the state. The harms and wrongdoings inflicted on individual workers were hardly addressed and the migrant workers themselves were not specified as objects for protection, i.e., as potential victims, in the tackling of economic crime. The paper argues that there is a need to move away from understanding labour violations solely in the framework of financial and fiscal harms, and to see labour exploitation as a crime that also violates the individual.
\end{abstract}

\section{Introduction}

The number of migrant workers in Finland has increased in recent years, although exact statistics are lacking (Hirvonen 2012). Simultaneously, the incidents of various types of exploitation of migrant workers have increased. Previous research has identified the restaurant, construction and agriculture sectors as venues where serious cases of exploitation of migrant workers have taken place. The known perpetrators are both Finnish citizens as well as people with a foreign background. The exploitation of migrant workers is multifaceted, ranging from salary discrimination and poor working conditions to isolation, threats and in rare cases even violence. At the worst, the exploitation experienced by migrant workers in 
Finland amounts to trafficking for forced labour. (Jokinen et al 2011a; Jokinen et al 2011b.)

Many of the cases of exploitation of migrant labour brought to justice have concerned small-scale family businesses, where the exploiter and the exploited are part of the same ethnic group, and in some cases, even relatives or acquainted with each other. There have however, recently been media accounts of cases brought to the attention of criminal justice actors of exploitation of migrant workers in organised industries, such as the plastic and metal industries.

There is a lack of available information on the extent of the incidents, but qualitative studies, reports to labour unions, and the findings regarding the problems of control indicate that the vast majority of cases do not come to the attention of the criminal justice agents. If they come, many of them are not investigated or are considered under a more lenient crime title than would be possible. Cases may also be dealt with as financial crime, where the victim is the state or another corporation. (See Jokinen et al 2011a; Jokinen et al 2011b; Alvesalo-Kuusi et al forthcoming.)

However, there are indications of a recent shift in focus with the police increasingly investigating cases of serious exploitation. In 2006 the police and the Finnish border guard recorded 11 offences of extortionate work discrimination, ${ }^{3} 2$ offences of trafficking in human beings, and 4 offences of aggravated trafficking in human beings. ${ }^{4}$ In 2011 the figures had increased substantially: 37 cases of extortionate work discrimination were recorded, 28 cases of trafficking in human beings, and 7 cases of aggravated trafficking in human beings. (Oikeusministeriö 2012,37.) Until 2009 there were only a handful of persons annually sentenced for extortionate work discrimination. In 2009, 12 persons were sentenced and in 2010, 4 persons were sentenced for extortionate work discrimination (Statistics Finland 2006-2011). The first conviction for trafficking for forced labour in Finland were passed only in March 2012. To date, a total of 4 persons have been sentenced for trafficking for forced labour by Finnish courts of law. ${ }^{5}$

Regulating economic crime has been one of the priorities of crime control in Finland. Since 1996, the Finnish government has launched six action plans against economic crime and the grey economy. But crimes against migrant workers, and work offences in general, have played a minimal role in the context of economic crime enforcement. This reflects the conventional wisdom within criminology, to the effect that in the rare instances that regulation and enforcement does proceed against business offences then this tends to encompass "economic" as opposed to "social" offending. An elaborating example on the priority of economic harms over social harms can be seen in what happened in a special police 
unit, the so called Illegal Migrant Labour Unit (IMLU). During its existence (2004-2008), only a fraction of the cases investigated by the unit involved crimes where the victim was a migrant worker. In other words, despite the specific aim of the unit, the IMLU neglected to investigate infractions by employers against migrant employees, and instead concentrated its investigative energies on crimes against the state (tax-evasion) or crimes against other companies (fraud). (Eskola \& Alvesalo 2010.)

The underenforcement of crimes against migrant labour is not due to the lack of legislative tools: the Finnish criminal law includes several crime titles, where violations against migrant labour, or labour in general, are sanctioned. ${ }^{6}$ But the enforcement of the law does not always follow its codification. The Finnish actors of the criminal justice system have had difficulties in constructing the crimes, in identifying the victims and they have been somewhat reluctant to recognise the exploitation of migrant labour as a legitimate target of police intervention. In addition, the investigation of such matters is not clearly allocated to specific police units, an ambiguity created by the organisation of policing ensuring that they are "nobody's property" (Jokinen et al 2011a; Jokinen et al 2011b; Eskola \& Alvesalo 2010; Alvesalo-Kuusi et al forthcoming). Criminal justice agencies do not simply follow the letter of the law, but enjoy a large measure of discretion within the law. The police, through their activities, have their role in defining who may and may not be criminalised; the practice of policing itself contributes to developing common-sense assumptions about what and who are the legitimate objects of crime control. (Lacey 1994; Alvesalo \& Whyte 2007; Loftus 2009.)

The underenforcement of corporate crime in general results from a combination of a general lack of political priority given to regulation, and of the dominant ideological assumptions that underpin the regulation of business. Macro economic and political factors may play an important role in shaping the criminal justice agents world-views and influence the possibilities and willingness for effective enforcement (Tombs \& Whyte 2007, 164.) The level and intensity of state commitment can be decisive in shaping collective perceptions of crime and shared understandings of the risks of and harms caused by criminal behaviour (Barak 1994). Police as government agents are trusted with the enforcement and therefore influenced by political priorities (Alvesalo \& Tombs 2001).

The regulation of exploitation of migrant labour in Finland takes place in the context of the ideological and political framework of labour market, immigration and crime policies as well as in a historical continuum where especially EU policies influence actions taken. In this paper we will look empirically at how migration, migrants and the exploitation of migrant workers are portrayed in govern- 
mental policy documents during the years 1995-2012. The empirical data was derived from an analysis of key governmental documents from these years (see the list of references). ${ }^{7}$

We look at how the issues of exploitation of migrant labour, economic crime, and trafficking in human beings for the purpose of forced labour emerged and merged in the government programmes and policies. We outline how the migrant (workers) were perceived in general; how the exploitation of migrant labour was portrayed; how the exploitation of migrant labour was linked to economic crime; how migrants were perceived as criminals and as victims, and; how and if these perceptions have changed over the years.

Our starting point is that the actions and inactions of the police and other control authorities, and state regulation in general, can only be comprehended within a broad recognition of social forces. These forces need to be identified and their dialectical relationships traced and understood. (see e.g. Snider 1991). Before presenting the results of our analysis, we present a short history of the development of Finnish migration policy. We also discuss how the exploitation of migrant labour can be understood as corporate crime and how this conceptualisation and analysis thereof could help understand the current underenforcement of these incidents.

\section{Exploitation of migrant labour at the nexus of movement and control}

The Finnish refugee and immigration policy lacked clear rules, aims and comprehensive planning until 1997, when the first Government programme on migration was approved. Simultaneously, stemming from the shifts in the international order, the issue of immigration became framed as a question of threats to internal security, and measures became more controlling, especially concerning asylum seekers. (Salmio 2000.)

The representatives of employers were already in the 1970's raising concerns about the potential lack of labour in Finland. ${ }^{8}$ At the time, the arguments mostly focused on the need to attract emigrated Finnish citizens back to the motherland. The recession of the 1970's terminated this discussion. The need for foreign labour was raised again at the turn of the 1980's and 1990's, but again the plans were put to a halt due to the recession in the early 1990's. (Forsander 2002, 20 21.) The recession also changed Finnish labour markets with the status of less valued jobs decreasing and income disparities increasing, and unstable jobs becoming more common (Salmenhaara 2008). The approach towards migration does not come about in isolation, but is tied to developments in the international community. Finland's immigration policies and related regulation have for the 
last 20 years been strongly influenced by international obligations - especially by the European Union - rather than internal needs or pressure (Forsander 2002; Forsander et al 2004.)

Proactive labour migration was introduced in Finland as a government policy in 2006, and migrant labour was considered the solution to the labour demand. Critical voices against migration in general (especially regarding the costs relating to asylum seekers and refugees) did exist also in the past (Salo 2005), but the local elections in 2008 politicised the issue of migration to a level that had not been experienced before (Simola 2010; Keskinen 2009). In recent years the discussion has focused especially on managing migration (Vuokrikuru 2012). Labour migration by default inherently is full of contradictions and encompasses people with different backgrounds and reasons for their migration and is thus difficult to manage and control (c.f. Himanen \& Könönen 2010, 96-97).

The number of international migrants in the world has grown over recent years and is expected yet to increase in the near future as the labour force is rapidly growing in less developed countries (IOM 2010). The ageing population and the increasing dependency ratio in the developed world simultaneously create an increased need for migrant workers in Europe and also in Finland (see e.g. European Migration Network 2011; Liukko 2010). The need for labour migration is a rhetoric, promoted by the EU (e.g. Hansen 2010, 91). While measures have been undertaken to promote certain forms of labour migration, other measures have been implemented to protect the external borders from unwanted migrants. The increase in irregular migration into the European Union is a result of labour market demand for cheap and flexible labour, and this labour, provided by irregular migrants, has become a structural necessity (Hansen 2010, 90). In connection to this, there also seems to be an idea of a causal link between immigration and the perceived threats posed by crime, deviance and conflict related to uncontrolled immigration (see Albrecht 2002). The European Union's efforts to develop a common immigration policy illustrate both aspects: legal immigration is to be promoted, but should be based on an assessment of needs in the EU labour markets, while illegal immigration is to be prevented, with zero-tolerance for trafficking in human beings (European Commission 2008; 2011). The control measures however have been criticised for having had little effect, leading to the conclusion that perhaps it is the means of management, rather than the phenomenon of migration itself, which is the main problem (Forsander et al 2004, 81). All in all it is evident that EU policies help separate migrants into wanted immigrants and immigrants considered unwelcome (Albrecht 2002; Chou 2008; Hansen 2010; Hud- 
son 2007). This division may also affect the way the police and other control authorities act.

Although the EU aims at restricting illegal entry, EU policies in fact enable increased irregular migration, much at the cost the migrants themselves (Hansen 2010). The ambiguity regarding the role and status of the migrant worker is closely connected also to the ongoing discussion regarding migrant labour in Europe, where the migrants are regarded both $a$ risk and at risk (see Aradau 2004). Within the Finnish criminal justice system the former seems to be emphasised over the latter; migrants are rather constructed as suspects than victims (Alvesalo et al forthcoming). ${ }^{9}$

Migrants have become at risk particularly as a result of the segregation of work and labour markets. Neo-liberalism and economic deregulation have lead to an informalisation of the economy also in countries with formerly highly regulated labour markets. Subcontracting, temporary work and the casualization of labour move work from the formal to the informal economy. (Castles 2012, 13-14.) The more difficult it is for migrants to obtain legal work and legal (work or residence) permits, the more likely it is that they turn to illegal employment and criminality, thus confirming the prejudices against them (Enzensberger 2003).

The exploitation of migrant labour falls under the criminological category of corporate crime. Corporate crimes are illegal acts or omissions, which are the result of deliberate decision making or culpable negligence within a legitimate formal organisation, most commonly limited liability companies. The exploitation of migrant labour consists of economic misuse, unfair labour practices and violent corporate illegalities, such as unsafe working conditions. Criminological literature includes interesting analyses on the underlying factors behind the invisibility of corporate crime, on why and how it is not treated as crime. Corporate crime in general is excluded from criminal policy and enforcement by a range of mutually re-enforcing political, ideological and structural factors.

Certain forms of corporate crime, most notably financial crimes and serious fraud in particular, have been more likely to be subject to demands for effective regulation than health and safety and environmental crimes, for example (Slapper \& Tombs 1999, 87). Snider $(2000,172)$ has differentiated "financial crimes" from "social crimes" in that the former victimises the financial markets, competitors and consumers and in the latter, the primary victims are employees and the general public. It has been argued that the reason for the interest in financial crimes is that they, unlike social crimes, threaten the effective functioning of capitalism (Punch 1996, 39; Levi 1993, 79). In turn, to define social crimes, e.g. 
crimes of the employers against (migrant) employees as targets of official crime policies may jeopardize the effective functioning of capitalism.

At the same time however, the current economic order - supported by deliberate economic policies - is creating an increased demand for cheap and flexible labour and this very labour is increasingly provided by migrants, contributing to an increasing segregation of labour markets (see e.g. Hansen 2010; Castles 2012). The segregation in turn, may promote exploitation of (migrant) labour as well as the growth of the grey economy. Crime control policies, regulation and the actions (and inactions) of the police thus exist in a crossfire of contradicting aims and priorities.

In many EU countries the cheap and flexible labour provided by irregular migrants has become a structural necessity (Hansen 2010) and it may well be that the regulation of the use - not to mention misuse - of such labour is not raised high on the political agenda. According to Snider $(2000,171)$, states compete over global capital by offering the highest corporate subsidies, the lowest taxes and costs of labour and the weakest level of corporate crime regulation. When left to its own devices, the state will not provide enforcement at the level required by its own legislation and that it will settle into providing a level of enforcement the target can live with (Snider 1991, 211). The underenforcement of corporate crime results from a combination of a general lack of political priority given to regulation, and of the dominant ideological assumptions that underpin the regulation of business. Under neo-liberal conditions of de-regulation and privatisation, punitive enforcement is not perceived as a feasible option. Macro economic and political factors may play an important role in shaping the criminal justice agents worldviews and influence the possibilities and willingness for effective enforcement (Tombs \& Whyte 2007, 164.)

We will next turn to presenting the results of the analysis of Finnish Government documents to show how the of exploitation of migrant labour, economic crime, and trafficking in human beings for the purpose of forced labour emerged and merged in the government programmes and policies over the period of 19952012.

\section{Exploitation of migrant labour and the grey economy in Government documents 1995-2012}

\subsection{Picking cherries and strengthening the skills matrix of the population}

The government documents, especially at the beginning of the period under scrutiny, portrayed migrant labour as a solution to the threat posed by the (perceived) labour shortage in Finland. In light of the rather uncoordinated and restrictive mi- 
gration policy of the past, the first Finnish government programme on migration and refugees of 1997 introduced the idea of regulated but wanted migration. In a controlled manner, Finland was to cherry-pick the positive aspects of globalisation, consequent migration as well as Finland's new membership in the European Union. "Finland shall purposefully utilise the positive aspects of this development while minimizing its negative effects as far as possible" (MIG 1997, 1). Skilled and exceptionally competent migrants were to be favoured, with work permits to be issued mainly for "professional labour and for work that requires skills" (MIG 1997, 10). In addition, temporary and seasonal migration was also to be enhanced through exchange of internships, for example (MIG 1997, 11).

The idea of migrant labour as a solution to Finland's future adverse population structure was further emphasised at the turn of the millennium. Together with a focus on economic growth, the challenges caused by the aging population were key features of the government programmes on both sides of the millennium. Contrary to the previous programme, the government foresaw that an active, comprehensive and consistent immigration policy was to solve the problems of gaps in skills and labour demand. In 2003, the government in its programme called for measures to enhance the labour supply, through "preparing to receive also foreign labour" in the future (GP 2003, 9). The demographic development was seen lead to "a completely new situation", which could only be resolved through increased labour migration. "When the dependency ration so presumes, the government will promote a policy of labour migration" (ibid., 22).

A shift in the approach towards migrant labour can be traced during this period: the government was increasingly promoting an active migration policy (MIG 2006) to support a positive employment development and a stable economic policy (EMP 2003/2006). At the same time, the idea of "cherry-picking" skilled labour to fill gaps among the population was still present. "The immigration of foreign employees and their family members shall be promoted to safeguard the availability of a skilled workforce and strengthen the skills matrix of the population" and "immigrants can help ease the shortage of labour, widen the skill-base and make innovations" (MIG 2006, 2; 4). Although the programme for the first time introduced active immigration efforts as a solution, the cherry-picking also included an element of control: only certain migrants were wanted. Control of who was to be allowed to come to Finland was to be achieved e.g. through cooperation with countries of departure (MIG 2006, 5).

Towards the end of the period under scrutiny, the reduction in the active labour force due to the aging population was already considered a reality, and not just a future threat. Labour migration was to be consciously increased to fill gaps 
in skills and supply (GP 2007, 11) and foreign labour was portrayed as a commodity that could easily be acquired (EMP 2007, 4). The government prepared a specific action plan on labour migration in 2009. The action plan indeed portrayed labour migration as a solution to many problems in Finland, but there was also clearly a much deeper recognition of the necessity to consider all consequences of labour migration. The action plan maintained that more foreign workers are needed in the future especially in the service, social and health sectors, but that it was impossible to know the real need (LMIG 2009, 12-13). This idea of needs-based migration was emphasised also in the latest government programme from 2011. The vision of the current government is that fiscal sustainability will be improved through increased productivity, higher birth rates, and "more workbased immigration based on a genuine demand for labour" (GP 2011).

Integration of migrants, particularly asylum seekers and refugees, was officially introduced in the 1997 migration policy as a solution to ensuring that migrants or refugees incorporate into Finnish society with equal rights and responsibilities compared to other citizens. The migration programme mentioned that a law on asylum seekers and the integration of migrants was to be prepared. (MIG 1997.) ${ }^{10}$ Most of the integration measures however focused on asylum seekers and refugees. The need to incorporate also labour migrants into society was raised in the immigration programme of 2006, which noted that immigrants should not be considered "merely an instrument for solving a problem" (MIG 2006, 4). The programme highlighted the need for integration support not only for refugees and asylum seekers, but also for labour migrants and their families, including information on rights and responsibilities, working life and the rules of play, housing, education and training and factors needed to cope in everyday life (MIG 2006, 18-21).

\subsection{Illegal versus legal migrants and control as a fix-it all}

As described above, the government documents called for skilled and competent migrant workers, but not all migrants were seen to fulfil the categories of desired and wanted migrants. Throughout the time period under scrutiny, there is juxtaposition in the documents between illegal and legal migrants. There is a clear distinction to be seen where certain migrants are wanted, while others, especially illegal immigrants, pose a threat. This is furthermore in the documents framed in the context of an external threat. Illegal migration is additionally portrayed as a phenomenon linked to organised crime, lead by or connected to international crime groups or foreign crime organisations. 
As a new member state of the EU in the mid-nineties, Finland wanted to promote openness, human rights and also the free movement of citizens. But at the same time, there was a perceived need to prevent the threats caused by transnational organised crime and illegal immigration related to this increased movement. (MIG 1997, 1; 8.) Few concrete measures on how to prevent unwanted movements were suggested in the migration policy document apart of international cooperation and clear visa regulations.

The increasing number of foreign people in Finland, especially due to deficiencies in border control, was portrayed as a threat to security in the Internal security programme 2004-2007. In the section addressing border control, the focus was on scrutinizing the problems and prevention of undocumented individuals or the misuse of asylum and refugee regulations as well as false marriages (ISP 2004).

Trafficking in human beings became a (government) concern in the early 2000 's. The first national action plan against human trafficking of 2005 portrayed an increasing threat: illegal entry to and through Finland was seen to be on the rise with serious and organised crime increasingly involved. Internationally networked criminal organisations were considered efficient and well-coordinated, and this would lead to more potential victims who end up in prostitution or working for construction companies that use illegal labour (HUM 2005, 30). The plan seemed to mostly be concerned with risks related specifically to illegal foreign labour. "Through active labour protection measures the risk sectors in relation to illegal foreign labour, unjust treatment or discrimination will be monitored" (HUM 2005, 15). Accordingly, the first Government Migration Policy Programme 2006 made a strong link between "illegal employment of foreigners and organised operations in the informal economy", including tax evasion, and violation of minimum working conditions (MIG 2006, 39).

Trafficking in human beings can also take place in the context of fully legal employment. The Internal security programme of 2008 made this point: while paperless victims were considered the most vulnerable, not all victims are paperless, and also those with working-permits may become victims. Trafficking is thus not always connected to smuggling of people or illegal immigration. (ISP 2008,48 .) This is an important realisation, and unlike the other documents, the focus was moved away from organised crime and illegal employment.

However, the prevention of illegal entry and the related threat posed by organised crime seems to be a continuous thread in the programmes. The Government programme in 2007 emphasised that legal immigration was to be increased and illegal immigration and trafficking in human beings prevented (ibid., 22). Also 
the internal security programme pointed out how the amount of organised crime has increased. Crime lead from "elsewhere", including illegal immigration was defined as a threat and organised crime was defined as a key actor in the field of economic crime and traditional crimes against enterprises (ISP 2008, 11; 34). Also, "[i]llegal immigration into the European Union has continued apace and is increasingly connected to international organised crime, such as human smuggling and human trafficking" (ISP 2008, 13; 50). However, the programme stated that the enlargement of the EU has not increased the volume of human smuggling, illegal entry, or transit traffic through Finland, since "Finland is traditionally not an attractive final destination for illegal immigrants" (ISP 2008, 49; 51).

While migrant labour is in the documents presented as a solution to a threat to Finnish society - aging population, lack of labour - it is a solution that potentially itself also poses a threat to society - through the undermining of overall labour conditions - unless it is properly monitored and controlled. A common theme in several programmes is the improvement of the monitoring of labour conditions and terms, including those of migrant labour and posted workers (GP 2003, 22; EMP 2003). The control measures included the establishment of the special police unit (IMLU) (ISP 2004; HUM 2005). The role of labour inspectors in controlling the conditions of migrant labour was mentioned in several programmes (HUM 2005; MIG 2006; HUM 2008). It is however only in the most recent government programme that the Government stated that the role of labour inspectors was actually to be strengthened (GP 2011, 15; 66).

The documents also emphasise that control is not only to be implemented by authorities. In terms of human trafficking, labour organisations should be made sensitive to notice the possibility of human trafficking (HUM 2005, 11). More raids were called for especially in risky sectors such as the restaurant and cleaning sectors, where human trafficking cases easily remain univestigated (ibid. 53). Trafficking was to be prevented effectively through increasing control by authorities and by making users responsible, such as employers (HUM 2005, 13; 45).

\subsection{Linking the exploitation of migrant labour to economic crime and the grey economy}

The documents portray migration as involving certain risks, which can be managed through control measures. The documents frame migration often in the context of an external threat and portray it as a phenomenon linked to organised crime, lead by or connected to international crime groups or foreign crime organisations. The realization of control measures in the framework of economic crime emerged gradually in the new millennium. 
Since 1996, the Finnish government has launched action plans against economic crime and the grey economy (EC action plans). In all of the six EC action plans, emphasis is laid onto financial crimes i.e. economic crimes against the state (tax-evasion) or crimes against other companies (fraud). The chief arguments for control measures throughout all EC action plans are those to protect the markets, ensure fair competition, promote honest business and secure the state's incomes. The recognition of social crimes, where the objects of protection are employees, consumers and the general public, are in a marginal position. However, the second half of the time period under scrutiny (1995-2011) witnessed some recognition of social crimes and the exploitation of migrant labour in the context of economic crime and grey economy.

The first Government programme (GP 1995) under scrutiny promised that Finland would participate in the development of EU norms to improve labour and social protection, and that Finnish labour conditions would be applied to work carried out by foreigners in Finland. However, the first governmental EC action plan (EC 1996) had no reference to crimes against employees in general and migrant labour was not included with reference to crime or the grey economy. The second (EC 1999) and third (EC 2002) EC action plans recognised crimes against employees in the appendixes of the plans. The project lists of the action plans included some measures, e.g. a comprehensive debriefing on safety and environmental crimes and their control mechanisms. It was also mentioned that the health and safety officials, in their regulatory work, would more actively take economic crime into account. Hence, there was some recognition of crimes against employees in the context of economic crime but exploitation of migrant labour was not addressed.

Despite the minimal role of migrant labour in the EC action plans, recognition of the role of migrant labour in the context of economic crime and the grey economy could be found in other governmental documents in beginning the millennium. The Government programme of 2003 linked the grey economy with labour policy. As in previous government programmes, the prevention of economic crimes and the grey economy were also included as a priority under the heading of legal policy and safety of citizens. As was required in the programme, a working group was established (Ulteva 2), addressing subcontracting, temporary and agency work. ${ }^{11}$ In 2004, the Internal security programme (ISP 2004) raised economic crimes, together with violent crime and drug offences, as one of the main crime categories. Tax-evasion, crimes of the debtor and book-keeping crimes were named as the most relevant economic crimes. One of the ten measures against economic crime suggested in the programme was to control the terms of 
work of foreign labour more effectively. It was stated that the use of migrant labour had increased and lead to a partial bifurcation in the labour market, especially in agency work (ISP 2004, 42)

Coming into the new millennium, economic growth and employment were again the key priorities of the government. The prevention of the grey economy had become more prominent, especially as economic criminals were portrayed as more professional and organised. From 2005 onwards a common thread in the documents was the connecting of organised crime, internationalisation, and the increase in economic crime. In the programme on criminal policy for the years 2007-2011, globalisation and the free movement of capital and labour were anticipated to cause challenges. It was also predicted that crimes in the working life and environmental crimes would get more attention in the future (CP 2007, 15). Migrant labour was recognised as having an impact on economic crime control: "the expanding use of grey and foreign labour has affected the working environment of the officials significantly". (EC 2010,2)

The documents addressing migration policy and human trafficking also connected migration with the grey economy. The documents make strong links between illegal employment of foreigners and organised operations in the informal economy, including tax evasion, and violation of minimum working conditions. The first national action plan against human trafficking (HUM 2005) saw the expansion of organised criminal activities as a threat, and predicted that the victims of labour-related trafficking were expected to enter the "dark labour market" (HUM 2005, 30). The plan also links the grey economy to posted workers (HUM 2005, 15, 53-55).

The problems related to posted or agency work, were raised in many of the documents since 2005. Hand in hand with these precarious forms of employment, tax issues regarding the use of foreign work were addressed. The documents handled agency work and posted workers particularly in the framework of tax revenue, not addressing the harms and wrongdoings inflicted on individual workers. ${ }^{12}$ In the Government Programme 2007-2010, the prevention of the grey economy was mentioned in conjunction with taxation policy but it was not explicitly included under the section dealing with legal policy (GP 2007, 14). The following government prioritised several concrete measures, including the enhancement of the obligation for posted workers to pay taxes (GP 2010, 4). In line with this, the proposals referring to foreign labour in the economic crime action plan concentrated on tax-issues and on the possibilities to control the employers' compliance with the minimum standards of employment and labour law in the use of foreign agency work. The use of agency work was predicted to raise into daylight new 
forms of crimes (EC 2010). The latest EC action plan made proposals to broaden officials' rights to access information. It emphasised how "the obligations and rights concerning taxation should be the same for all employees living in Finland" (EC 2011, 6).

The prevention of the grey economy is one of the key priorities of the sitting Government (GP 2011, 15). This Government programme, for the first time, includes a separate section on the prevention of the grey economy. Economic crime and the grey economy are portrayed as major threats to society: the volume has increased and it has become more international and organised. The rationale behind this enhanced focus is the fact that the government debt burden could be reduced through increased funds received through taxes and social fees (GP 2011, $7 ; 15)$. The introduction of the obligatory tax number for each employee at construction sites is also mentioned, as is the intention of the Government to assess the functioning of existing regulation of migrant labour (GP 2011, 16). Compared to all other documents, the latest Internal Security programme also opens a new approach to address grey economy by handling it in also the context of safety at work. The documents emphasises the vulnerability of the grey labour force and also makes reference to the HEUNI research ${ }^{13}$ on the exploitation of migrant labour. (ISP 2012, 8)

\subsection{Migrants as criminals and eventually as victims of crime}

Even though the second half of the time period under scrutiny witnessed some recognition of social crimes and the exploitation of migrant labour in the context of economic crime and grey economy, and some recognition of migrants as victims of unfair labour market practises or economic misuse, it is interesting that migrant workers are seldom framed as victims of economic crime. The emphasised harms caused by the unwanted phenomena, i.e. misuse of foreign labour, are those inflected upon the state or fair competition. The chief arguments for control measures and actions against economic crime are those to protect the markets, ensure fair competition, promote honest business and secure the state's incomes.

Individuals in general, and migrants in particular, are seldom raised as the object of protection, as victims, in tackling economic crime. When discussing crime problems and victims of crime, focus is often laid on other issues, such as migrants as criminals, transnational and organised crime and racist crimes, but not on foreigners or migrants as victims of economic crime.

The first national general crime prevention programme (CP 1998) lacked reference to economic crime in general, and migrants as victims of labour exploita- 
tion were not mentioned. The main point of view regarding migrants was to prevent the criminality committed by migrants by minimizing their risks of social exclusion. It was emphasised, for example, that it is important to improve the possibilities of employment of vulnerable groups such as ethnic minorities (CP 1998, 22). The prevention of racist crime was also seen as important (CP 1998, 18). Six years later, the internal security programme (ISP 2004) saw advanced integration as a way to prevent racist crime on the one hand, and crimes committed by immigrants on the other (ISP 2004, 26). An indirect reference was made to migrants as victims of economic crime, as it was mentioned that the crime title extortionate work discrimination had been added to the Penal Code.

In 2005 the action plan against human trafficking portrayed labour trafficking taking place mostly in the so called dark labour sector (HUM 2005, 30). The plan noted that indications of exploitation of labour have been noticed in restaurants managed by foreign persons and on construction sites. The foreign origin of exploitation was present also in that Finland was considered a transit and destination country for hundreds of victims of both sexual exploitation and for the exploitation of labour (25).

The two national action plans to prevent trafficking in human beings established the right of victims of trafficking to receive state-sanctioned support and assistance. Both documents contained specific sections on the organisation, funding and principles of assistance to this group of victims (HUM 2005; HUM 2008). ${ }^{14}$ The government programme of 2007 mentioned that non-governmental organisations that engage in outreach and counselling to victims of human trafficking would receive governmental funding (GP 2007, 22). The most recent government programme highlighted the need to protect victims and enhance their protection under the law and also suggested that services to immigrants and victims of trafficking should be improved (GP 2011, 26; 51).

In the general programme on criminal policy for the years 2007-2011, it was predicted that the amount and forms of crimes committed by foreigners would increase, and this would cause racist reactions. Similar concerns on racism were brought forward in the internal security programme in 2008. "An increasing number of socially excluded people may, in the worst case, lead to a toughening of attitudes towards ethnic minorities and even to an emergence of isolated subcultures, both among the majority population and among ethnic minorities. So far, apparently no such sub-cultures have emerged in Finland. However, developments abroad have shown that the social exclusion and deprivation of ethnic minorities may lead before long to problems with major repercussions for society as a whole "(ISP 2008, 9). This programme raised a new threat regarding immi- 
gration: the section of terrorism highlighted that radicalization and terrorism may develop amongst immigrants. These threats were also raised in the latest Government programme in 2011.

The internal security programme of 2008 emphasised integration and included its own section on improving the safety of immigrants and ethnic minorities. This included measures such as access to security services and also measures against identifying and reacting against racist crime. (ISP 2008) The latest Government programme also states that it will work "purposefully against racism and discrimination" (GP 2011, 3). Accordingly, the latest programme for internal security (ISP 2012) raised racist crime as its own theme in the threat assessment. Interestingly, safety at work, labour exploitation or human trafficking are not addressed in the section on improving safety of immigrants (ISP 2012, 26; 29).

\section{Conclusions and discussion}

The analysed government documents show that the promotion of migrant labour was a central theme of government policies during the period under scrutiny. Skilled, mobile labour was to be hand-picked to solve national gaps in skills and the labour supply. Beginning from the early 2000 's, the promotion of labour migration was presented as a solution to the threat posed by the aging population, the perceived decrease of active labour force and thus a future adverse economic development. Migrant labour would help Finland grow and prosper and efforts were to promote easy entry of wanted and needed migrants.

At the same time, the freer movement was anticipated to attract illegal elements, including illegal immigration and organised crime. Migration was portrayed as involving certain risks, which could however be managed through control measures, especially at the borders, so as to promote the wanted migrants, while excluding the unwanted migrants. This approach towards migration did not come about in isolation, but has been influenced by international obligations rather than solely internal needs or pressures (Forsander 2002). ${ }^{15}$

In addition to controlling the external borders, the documents also picture another level of control, that of controlling the terms and conditions of work of foreign labour. The documents show a growing realisation that migrants may be subject to labour conditions that do not fulfil Finnish standards, and this in turn, may undermine the labour market in the country, thus posing a threat to Finnish workers (Alho 2010; Simola 2010; see Engblom 2010 for a similar discussion in Sweden). The government documents also imply that ultimately this is leading to a bifurcation of the labour market. Migrant labour is pictured as a solution to a 
threat to Finnish society, but as a solution that potentially also poses a threat to society unless properly monitored, managed and controlled.

The documents illustrate several levels of control, including the migrants' entry into the country, the migrants' existence and work in Finland, and the labour market itself. The various levels of control of migrant labour all serve to protect and secure the conditions of the Finnish labour market and ultimately the state. What seems to be lacking is a simultaneous awakening to the idea that the dual labour conditions in particular also mean that migrant labourers are themselves the targets of misuse and even exploitation. Furthermore few, if any, of the documents seem to consider labour migrants as individuals who may or may not wish to remain in the country, and who may want to become part of the society they work in. As Hansen (2010, 98-99) has pointed out, substantial rights are costly and fit badly in the current economic neoliberal doctrine, giving rise to the precarious and rightless position of migrant workers where they give their labour but receive nothing in return. Incidentally, the need for integration measures for labour migrants is raised only towards the end of the period under scrutiny.

In the second half of the time period under scrutiny there emerged some awareness of the exploitation of migrant labour in the context of economic crime and grey economy. But as has been pointed out by Slapper \& Tombs $(1999,87)$, regulation and enforcement tends to encompass "economic" as opposed to "social" offending. In the overall picture social crimes had a marginal role in the policy documents. Furthermore, economic crime in general and also the misuse of migrant labour were overwhelmingly addressed in the framework of problems related to tax revenue, fair competition and the functioning of the markets. Even though there was some recognition of migrants as victims of unfair labour market practises or economic misuse, the harms and wrongdoings inflicted on individual workers were hardly addressed, and migrants were seldom constructed as victims of economic crime. Migrant or foreign labour was lumped together and implicitly constructed as a commodity, which should be used in ways that does not cause harms to the Finnish labour-markets, Finland's tax revenue or Finnish companies.

Individuals in general, and migrants in particular, are seldom raised as the object of protection, as victims, in tackling economic crime. The victims of inappropriate use of migrant labour are the Finnish society and the markets. When discussing crime problems and victims of crime, focus is laid on other issues, migrants as criminals, transnational and organised crime and racist crimes, but not on foreigners or migrants as victims of economic crime. If victimhood was discussed in the Government documents, it was often emphasised that the exploitation of migrants is often transnational, organised, lead from abroad or happens in 
the "dark", informal sector. "Honest" Finnish companies as possible perpetrators of exploitation were not mentioned in the documents.

The documents addressing human trafficking formed a clear exception to how victimhood is understood. Trafficking in human beings was in these documents portrayed as a serious crime, with the subjects of this crime entitled to statesanctioned support and assistance. In the documents trafficking was initially linked to illegal migration and organised crime, and thus, to unwanted migration. This linkage constructs trafficking victims as a consequence of illegal or unwanted immigration rather than as solely a category of victims of crime. Lee (2011, 60 ) points out that victims of trafficking are seen as both victims and as irregular migrants, at the same time being both at risk themselves and risky to the state, and thus to be "rescued" through state interventions, all taking place in an immigration control framework. The identification of victimisation among exploited migrant workers - and ultimately trafficking for forced labour - is complex and raises questions of who is to receive (the rights of) victimhood.

Overall, the documents portrayed migrants both $a$ risk and at risk (see Aradau 2004). They are a risk as both importing organised crime and also as committing street crime. They are also a risk as a potentially socially excluded group, which in turn may lead to more criminal sub-cultures and even terrorism. Racist crimes are raised as a major risk with which migrants are confronted. But in some way becoming a victim of racist crime is, in some of the documents, seen as a consequence of the migrant populations' social exclusion and deprivation. This reasoning implicitly blames the victim: if you do not integrate or get employment, you may be subjected to racism and other problems with major repercussions for society as a whole.

Our previous research has revealed that even thought there exits a structural readiness in terms of legislation to tackle exploitation, the Finnish actors of the criminal justice system, specifically the police and prosecutors, have had difficulties in constructing the crimes and in identifying the victims. They have been lacking the conceptual readiness and an understanding to recognise the exploitation of migrant labour as a legitimate target of police intervention. (Jokinen et al. 2011a; Jokinen et al 2011b; Alvesalo et al, forthcoming.) Even the special police unit (IMLU) especially established to investigate illegal migrant labour neglected to investigate infractions by employers against migrant employees, and instead concentrated its investigative energies on crimes against the state (tax-evasion) or crimes against other companies (fraud). (Eskola \& Alvesalo 2010.)

Our analysis of governmental documents may offer some explanations to our previous findings. Policies laid down by governmental programmes and the por- 
trayals of problems constructed in them, may play an important role in shaping the world-views of criminal justice agents and influence the possibilities and willingness for effective enforcement (Tombs \& Whyte 2007, 164.) Furthermore, the current economic order - supported by deliberate economic policies - is creating an increased demand for cheap and flexible labour, which is increasingly provided by migrants (Hansen 2010; Castles 2012). This in turn, is contributing to an increasing segregation of labour markets, which promotes both the exploitation of migrant labour in particular as well as the growth of the grey economy in general.

Control authorities, such as the police, act in the context of contradicting policies, aims and priorities. Political priorities as well as international obligations affect the development of enforcement, legislation, and ultimately concrete enforcement. Exploitation of migrant labour is a multifaceted phenomenon: while the migrant worker may end up in an exploitative labour situation largely as a result of structural reasons, from a control policy perspective the migrant worker embodies several threats to society. As such, he/she is not primarily constructed as a victim of a crime.

In order to address the exploitation of migrant workers both on the structural as well as the personal level, there is a need to move away from constructing labour violations solely as crimes against the state, and see labour exploitation as a crime violating also individuals. The recent increase in cases of exploitation coming to the attention of control authorities as well as the increasing recognition of the vulnerabilities of especially precarious migrant workers, will hopefully lead to the understanding of these infractions as crimes also against individuals.

\section{Notes}

1. Natalia Ollus is Senior Programme Officer at the European Institute for Crime Prevention and Control, affiliated with the United Nations (HEUNI) in Helsinki, Finland. Her current work focuses on the prevention labour trafficking in the Baltic Sea region, and she has extensive international experience in the field of anti-trafficking, having worked also for the UN and the OSCE. She recently co-authored the first study on trafficking for forced labour in Finland and is currently preparing her $\mathrm{PhD}$ in the sociology of law on the same topic.

2. Anne Alvesalo-Kuusi is professor of Sociology of Law and Criminology at the University of Turku (Faculty of Law). She has published extensively in the area of economic and corporate crime control. Recently her research has focused on the problems of policing safety crimes and the misuse of migrant labour in Finland.

3. The offence of extortionate work discrimination was introduced into the Penal Code in 2004 in order to tackle the grey economy and the misuse of migrant workers.

4. The figures include both trafficking for sexual exploitation as well as trafficking for forced labour.

5. Helsinki District Court 30.3.2012; Pirkanmaa District Court 29.6.2012. 
6. The provisions of chapter 47 of the Penal Code dealing with labour offences are the most relevant, including the work safety offence $(1 \S)$, the working hours offence $(2 \S)$, work discrimination ( $3 \S)$, extortionate work discrimination ( 3 a $\S)$, the employment agency offence $(6 \S)$, and the unauthorised use of foreign labour ( 6 a §). Chapter 25 of the Penal Code includes the crime of trafficking in human beings, including for the purpose of forced labour.

7. We only included documents that had been commissioned and approved by the Government, and were part of the overall government policies at the time. Many ministerial-level programmatic documents were thus left outside of the scope of this analysis. The documents can be divided into six main categories: overall government programmes outlining the priorities of the government at the time; economic crime programmes; crime prevention programmes; migration policy programmes; labour policy programmes, and; programmes to prevent trafficking in human beings. We first read through all the documents (close reading) and prepared summaries of the main points relating to our research questions. We then prepared a summary of the documents in chronological order. After this, we reviewed the themes that emerged from the documents and grouped the main points from each document thematically. This thematic grouping forms the basis of our analysis. When referring to the documents we use abbreviations (see references).

8. Several authors have argued that the high share of women among the Finnish labour force impacted the labour supply and reduced the need for recruiting labour from other countries (see e.g. Salmenhaara 2008; Forsander et al 2004).

9. A similar situations seems to exist in the other Nordic countries. See Øien and Sønsterudbråten (2011) for a discussion on how current policies in Norway contribute to placing (irregular) migrants on the boundary between legality and illegality.

10. The first act on the integration of migrants and asylum seekers was passed in 1999 $(439 / 1999)$ and was replaced by the act on the promotion of integration, passed in 2011 (1386/2010).

11. Ulteva 1 (the predecessor of Ulteva 2) was established by the Ministry of Labour in 2001 to meet the demands of the European Union. Its task was to examine the needs to intensify the surveillance of labour law obligations when foreign labour is used.

12. The EC action plan of 2006 made reference to the work of the Ulteva 2 group, which was to prepare the Act on the Contractor's Obligations and Liability when Work is Contracted Out, a law regulating situations where Finnish or migrant temporary agency workers or subcontracting are used. The main aim of the law was specifically to prevent grey economy and to secure fair competition.

13. Jokinen et al 2011a; Jokinen et al 2011 b.

14. A national system of assistance for victims of human trafficking was established in 2006. The system is coordinated by one state reception centre for asylum seekers. The assistance is based on an amendment of the act concerning the integration of immigrants and the reception of asylum seekers (1269/2006). An inter-ministerial working group is currently discussing the need for a separate law addressing support to victims of human trafficking, with the law proposal to be finalised by the end of 2013 .

15. The government policies under the period of scrutiny reflect developments in the international community (primarily the European Union but also the United Nations) in that they address border security and transnational organised crime in particular. 


\section{References}

Act on the Integration of Immigrants and Reception of Asylum Seekers, 493/1999.

Act on the Promotion of Integration of Immigrants, 1386/2010.

Act on the Integration of Immigrants and Reception of Asylum Seekers, 1269/2006.

Albrecht, Hans-Jörg (2002). Fortress Europe? Controlling Illegal Immigration. European Journal of Crime, Criminal Law and Criminal Justice, Vol. 10/1, 1-22.

Alho, Rolle (2010). Maahanmuuttajien kokemukset ja ammattiliittoen näkemykset työehtojen polkemisesta Suomessa. In Wrede, Sirpa \& Nordberg, Camilla (eds.) Vieraita työssä. Työelämän etnistyvä eriarvoisuus. Palmenia-sarja 70. Helsinki: Gaudeamus Helsinki University Press.

Alvesalo, Anne \& Tombs, Steve (2001). Can Economic Crime Control be Sustained? Innovation: the European Journal of Social Science Research 14 (1), 35-53.

Alvesalo, Anne \& Whyte, Dave (2007). Eyes Wide Shut: The Police Investigation of Safety Crimes. Crime Law and Social Change, Vol. 48, No. 1-2, 57-72.

Alvesalo-Kuusi, Anne, Jokinen, Anniina \& Ollus, Natalia (forthcoming). The Exploitation of Migrant Labour and the Problems of Control in Finland.

Aradau, Claudia (2004). The Perverse Politics of Four-Letter Words: Risk and Pity in the Securitisation of Human Trafficking. Millennium: Journal of International Studies. Vol. 33, No. 2, 251-277.

Barak, Gregg (1994) (ed.). Media, Process, and the Social Construction of Crime: Studies in Newsmaking Criminology. New York: Garland Publishing.

Castles, Stephen (2012). Migration, precarious work and rights: Historical and current perspectives. Introductory address at the UNESCO-MOST conference 2012 "Labour rights as human rights? Migration, labour market restructuring, an the role of civil society in global governance. Norrköping May 30-June 1, 2012.

Chou, Meng-Hsuan (2008). The European Union and the Fight Against Human Trafficking: Comprehensive or Contradicting? St Anthony's International Review, Vol. 4, No. 1, 79-95.

Engblom, Samuel (2010). Labour Law, Trade Unions and Irregular Migrant Workers. Presentation held at the Misuse of Migrant Labour-seminar. Helsinki 27-28.9.2010.

Enzensberger, Hans Magnus (2003). Suuri muutto. 33 merkintää. (originally Die Grosse Wanderung. 33 Markierungen. Suhrkamp Verlag Frankfurt am Main 1992, translated by Riitta Virkkunen). In Lehtonen, Mikko \& Löytty, Olli (eds.) Erilaisuus. Tampere: Vastapaino.

Eskola, Kaisa \& Alvesalo, Anne (2010). Ulkomaiseen työvoimaan liittyvät väärinkäytökset poliisin tutkimat tapaukset. Työterveyslaitoksen tutkimusraportti.

European Commission (2008). A Common Immigration Policy for Europe: Principles, actions and tools. Communication from the Commission to the European Parliament, the Council, the European Economic and Social Committee and the Committee of the Regions. Brussels 17 June 2008. COM(2008) 359 final.

European Commission (2011). The Global Approach to Migration and Mobility. Communication from the Commission to the European Parliament, the Council, the European Economic and Social Committee and the Committee of the Regions. Brussels 18 November 2011. $\operatorname{COM}(2011) 743$ final.

European Migration Network (2011). Satisfying Labour Demand Through Migration. European Migration Network. June 2011. 
Forsander, Annika (2002). Luottamuksen ehdot. Maahanmuuttajat 1990-luvun suomalaisilla työmarkkinoilla. Väestöntutkimuslaitoksen julkaisusarja D39/2002. Helsinki: Väestöliitto.

Forsander, Annika, Raunio, Mika, Salmenhaara, Perttu \& Helander, Mika (2004). Sykettä ja suvautsevaisuutta. Globaalin osaamisen kansalliset rajat. Helsinki: Edita.

Hansen, Peo (2010). More Barbwire or More Immigration, or Both? EU Migration Policy in the Nexus of Border Security Management and Neoliberal Economic Growth. The Whitehead Journal of Diplomacy and International Relations. Winter/Spring 2010, 89-101.

Himanen, Markus \& Könönen, Jukka (2010). Maahanmuuttopoliittinen sanasto. Into: Helsinki.

Hirvonen, Markku (2012). Ulkomaista työvoimaa koskevan sääntelyn toimivuus. Polisihallituksen toimeksiannosta tehty selvitys. Harmaa Hirvi Oy 9.3.2012.

Hudson, Barbara (2007). The rights of strangers: Policies, theories, philosophies. In Lee, Maggy

(ed.) Human Trafficking. Cullompton and Portland: Willan Publishing.

Jokinen, Anniina, Ollus, Natalia ja Viuhko, Minna (2011a). Ehdoilla millä hyvänsä. Työperäinen ihmiskauppa ja ulkomaalaisten työntekijöiden hyväksikäyttö Suomessa. Heuni Publication Series No. 67. Helsinki: HEUNI.

Jokinen, Anniina, Ollus, Natalia ja Viuhko, Minna (2011b). Work on Any Terms: Trafficking for Forced Labour and Exploitation of Migrant Workers in Finland. In Jokinen, Anniina, Ollus, Natalia \& Aromaa, Kauko (eds) Trafficking for Forced Labour and Labour Exploitation in Finland, Poland and Estonia. Heuni Publication Series No. 68. Helsinki: HEUNI.

Keskinen, Suvi (2009). Pelkkiä ongelmia? Maahanmuutto poliittisen keskustelun kohteena. In: Keskinen, Suvi, Rastas, Anna \& Tuori, Salla (eds) En ole rasisti, mutta ... Maahanmuutosta, monikulttuurisuudesta ja kritiikistä. Tampere: Vastapaino \& Nuorisotutkimusverkosto.

Lacey, Nicola (1994). Introduction: Making Sense of Criminal Justice. In Lacey, N. (ed) Criminal Justice. Oxford: Oxford University press, 1-35.

Lee, Maggy (2011). Trafficking and global crime control. London: SAGE.

Levi, Micheal (1993). The Investigation, Prosecution and Trial of Serious Fraud. The Royal Commissin on Criminal Justice, Research Study No. 14. London: HMSO.

Liukko, Matti (2010). Suomen ikärakenteen muutos työvoiman saatavuuden ja huoltosuhteen haasteena. In: Huttunen, Hannu-Pekka \& Ääriälä, Suvi (eds.) Avoin Suomi - kuka vastaa? Työperusteisesta maahanmuutosta. Helsinki: Uudenmaan elinkeino-, liikenne- ja ympäristökeskus.

Loftus, Bethan (2009). Police Culture in a Changing World. Clarendon Studies in Criminology. Oxford: Oxford University Press.

Oikeusministeriö (2012). Ihmiskauppatyöryhmän mietintö. Mietintöjä ja lausuntoja 63/2012. Oikeusministeriö: Helsinki.

Punch, Maurice (1996). Dirty Business. Exploring Corporate Misconduct. Analyses and Cases. London: SAGE Publications.

Salmenhaara, Perttu (2008). From Horizontal to Vertical Divides: Immigrants' Employment in Finland in the 1990s. Finnish Journal of Ethnicity and Migration. Vol. 3, No. 1, 13-20.

Salmio, Tiina (2000). Kylmän sodan loppuminen a EU-jäsenyys muuttivat Suomen maahanmuuttopolitiikkaa. Turku: Siirtolaisuusinstituutti. (www.migrationinstitute.fi)

Salo, Mika (2005). Suomi suomalaisille. Argumentit maahanmuuttoa vastaan Suomessa vuosina 1990-2003. Web reports No. 6. Siirtolaisuusinstituutti. 
Simola, Anna (2010). Miten tervetulleesta työvoimasta tuli uhka? In Huttunen, Hannu-Pekka \& Äärilä, Suvi (eds.) Avoin Suomi - kuka vastaa? Työperusteisesta maahanmuutosta. Helsinki: Uudenmaan elinkeino-, liikenne- ja ympäristökeskus.

Slapper, Gary \& Tombs, Steve (1999).Corporate crime. London: Longman Criminology Series.

Snider, Laureen (1991). The Regulatory Dance: Understanding Reform Processes in Corporate Crime. International Journal of the Sociology of Law, 19, 209-236.

Snider, Laureen (2000). The Sociology of Corporate Crime: An Obituary (or: Whose Knowledge Claims Have Legs?). Theoretical Criminology, 2000, 4:2, 169-206.

Statistic Finland (2006-2011): Justice statistics (in electronic format). Statistics Finland website.

Tombs, Steve \& Whyte, Dave (2007). Safety Crimes. Collumptom: Willan.

Vuorikuru, Ilkka (2012). Hallitun maahanmuuton hallinta poliittisessa keskustelussa. In Vuorikuru, Ilkka (ed.) Maahanmuutto harmaan talouden kysymyksenä. Kalevi Sorsa säätiön julkaisuja 2/2012. Helsinki: Kalevi Sorsa säätiö.

Øien, Cecilie \& Sønsterudbråten, Silje (2011). No way in, no way out? A study of living conditions of irregular migrants in Norway. Fafo-report 2011:03. Oslo: Fafo.

\section{Governmental documents (in chronological order)}

GP 1995. Government programme of Prime Minister Paavo Lipponen, 13.4.1995-15.4.1999.

EC 1996. Valtioneuvoston periaatepäätös 1.2.1996 toimintaohjelmaksi talousrikollisuuden ja harmaan talouden vähentämiseksi. (Decision of principle on the action plan to reduce economic crime and grey economy 1.2.1996).

MIG 1997. Valtioneuvoston periaatepäätös maahanmuutto- ja pakolaispoliittiseksi ohjelmaksi 16.10.1997. (Resolution for a Government programme on migration and refugee policy on 16 October 1997).

CP 1998. Turvallisuustalkoot - Kansallinen rikoksentorjuntaohjelma, Oikeusministeriö, Rikoksentorjunnan neuvottelukunta 1998.

EC 1999. Valtionneuvoston periaatepäätös kansalliseksi rikoksentorjuntaohjelmaksi 4.3.1999. (Decision of principle on a national crime prevention programme 4.3.1999).

GP 1999. Government programme of Prime Minister Paavo Lipponen, 15.4.1999-17.4.2003.

EC 2002. Valtioneuvoston periaatepäätös talousrikollisuuden ja harmaan talouden vähentämiseksi 20.6.2001. (Desicion of principle on the action plan to reduce economic crime and grey economy 2.6.2001).

GP 2003. Government programmes of Prime Minister Anneli Jäätteenmäki, 17.4.200324.6.2003 and Prime Minister Matti Vanhanen, 24.6.2003-19.4.2007.

EMP 2003. Hallituksen työllisyysstrategia ja työllisyyden politiikkaohjelma 2003-2007.

ISP 2004. A safer community. Internal Security Programme 2004-2007. Ministry of the Interior publications 44/2004.

HUM 2005. Ihmiskaupan vastainen toimintasuunnitelma. Helsinki 2005. Ulkoasiainministeriön julkaisusarja.

EC 2006. Valtioneuvoston periaatepäätös talousrikollisuuden ja harmaan talouden vähentämistä koskevaksi torjuntaohjelmaksi vuosille, 9.2.2006.

MIG 2006. Hallituksen maahanmuuttopoliittinen ohjelma 19.10.2006. Työhallinnon julkaisu 371/2006. (Government Migration Policy Programme, Government Resolution 19.10.2006). GP 2007. Government programme of Prime Minister Matti Vanhanen,19.4.2007-22.6.2010. 
EMP 2007. The Policy Programme for Employment, Entrepreneurship and Worklife 2007-2011.

CP 2007. Criminal policy in the welfare state. Ministry of Justice programme on criminal policy 2007-2011.

ISP 2008. Safety first. Internal Security Programme 2008-2011. Ministry of the Interior publications 25/2008.

HUM 2008. Revised National Plan of Action against Trafficking in Human Beings. Migration. Publications of the Ministry of the Interior 29/2008. Helsinki: Ministry of the Interior.

LMIG 2009. Työvoiman maahanmuuton toimenpideohjelma. Maahanmuutto. Sisäasiainministeriön julkaisuja 23/2009. Sisäasiainministeriö.

EC 2010. 5. 17.12.2009 Valtioneuvoston periaatepäätös hallituksen toimintaohjelmaksi talousrikollisuuden ja harmaan talouden vähentämiseksi vuosina 2010-2011.

GP 2010. Government programme of Prime Minister Mari Kiviniemi, 22.6.2010-22.6.2011)

GP 2011. Government programme of Prime Minister Jyrki Katainen, 22.6.2011-

EC 2012. Valtioneuvoston periaatepäätös 19.1.2012 tehostettu harmaan talouden ja talousrikollisuuden torjunnan toimintaohjelma vuosille 2012-2015.

LAB 2012. The Strategic Programme for Structural Change and Well-functioning Labour Market 2012-2015 and the Government Resolution for Securing a Well-Functioning Labour Market and Labour Supply of 31 May 2012.

ISP 2012. Turvallisempi huominen. Sisäisen turvallisuuden ohjelma. Helsinki 2012. 26/2012. 